epithelial cells obtained from millipore filter imprints of the conjunctiva in some patients with dry eyes, but did not find these changes in scrapings from these patients.

Perhaps our patient and Marner's patients with keratitis sicca who had these serpiginous changes really have a form of SLK. On the other hand, perhaps SLK and keratitis sicca have features in common which induce these serpiginous changes.

The cause of this unusual morphology remains obscure as does the cause of SLK. Should these changes be found in other conditions, similarities between such a condition and SLK may help explain the aetiology of SLK.

Department of Ophthalmology,

College of Medicine,

University of Cincinnatı,

Cincinnati, Ohio 45267 , U.S A

ARden H. WANDER

Department of Pathology,

and Laboratory Medicine,

College of Medicine,

University of Cincinnat

Teruo Masukawa

\section{AXILLARY OR RECTAL TEMPERATURES IN} CHILDREN?

SIR,-The small but real risk of rectal perforation, ${ }^{1}$ the comfort of the patient, and the preference of those taking temperatures in children make axillary measurement an attractive alternative to rectal measurement. Correlation of axillary and rectal temperatures by glass thermometry involves waiting $7-10 \mathrm{~min}$ for accurate temperature equilibrium in the axilla, but with the electronic thermometer axillary temperature can be determined within a few seconds. Many clinicians feel that the rectal thermometer is an anachronism. One of us (M. D. K.) agreed that the risks of rectal probing were no longer justifiable while the other (K. P.) remained unconvinced. Hence this study.

In five inpatients aged 14-28 months rectal, right axillary, and left axillary temperatures were recorded in quick succession and on several occasions. A separate group of seven children, aged 3-7 years, had oral, right axillary, and left axillary temperatures recorded. All measurements were made with the IVAC R821 electronic thermometer.

Each axilla served as a control for the other. In both rectal and oral groups, the difference between right and left axillary temperatures was $0 \cdot 0 \pm 0 \cdot 3^{\circ} \mathrm{C}$ (mean $\pm \mathrm{SD}$ ). This demonstrated reproducibility of measurement technique. Further calculations were then based on right axillary measurements.

In the younger children, the axillary readings were lower than the rectal readings by $0 \cdot 9 \pm 1 \cdot 0^{\circ} \mathrm{C}$. The large $\mathrm{SD}$ makes any attempt at conversion from axillary to rectal meaningless for clinical purposes: an axillary temperature of $37.1^{\circ} \mathrm{C}$ would indicate that the rectal temperature is likely to be somewhat higher but the interpreter could not tell whether it indicated fever or not since $37.1^{\circ} \mathrm{C}$ in the axilla is as likely to correspond to a rectal temperature of $39 \cdot 0^{\circ} \mathrm{C}$ as to one of $37 \cdot 0^{\circ} \mathrm{C}$. Where the rectal temperature was $37 \cdot 5^{\circ} \mathrm{C}$ or less the rectal-axillary difference was $0.6 \pm 0.4^{\circ} \mathrm{C}$ but when rectal temperatures were greater than $37.5^{\circ} \mathrm{C}$ the axillary readings were $1 \cdot 1 \pm 0 \cdot 2^{\circ} \mathrm{C}$ lower $(\mathrm{p}<0 \cdot 001)$. Thus the magnitude of the axillaryrectal temperature difference changes with the rectal temperature, and, although axillary temperatures are generally lower than rectal ones, no conversion can make an axillary temperature a reliable indicator of the temperature in the rectum. The same seems to be true for axillary and oral temperatures in older children. When the oral temperature was $37 \cdot 0^{\circ} \mathrm{C}$ or less the oral-axillary difference was $0 \cdot 1 \pm 0 \cdot 5^{\circ} \mathrm{C}$, while higher oral temperatures were associated with greater oral-axillary differences $0.5 \pm 0 \cdot 4^{\circ} \mathrm{C}$ higher $(p<0 \cdot 01)$.

We propose that axillary temperatures no longer be used for determining presence or absence of fever. Older, cooperative children may have oral temperatures checked, and the younger ones

1. Merenstein GB. Rectal perforation by thermometer. Lancet 1970; 1: 1007.

2 Blaney CG. Site selection in taking body temperature. Am f Nurs 1974; 74: 1859-61.

3. Nichols GA, Fielding JJ, McKevitt RK, et al. Takıng oral temperatures of febrile patients. Nurs Res 1969; 18: 448-50.

4. Nichols GA, Ruskin MM, Glor BAK. Oral, axillary and rectal temperature determinations and relationships. Nurs Res 1966; 15: 307-10. should have temperatures taken rectally. The youngest infants face the highest risk of perforation. In the newborn, better rectal-axillary correlation than we have found for children over fourteen months has been reported. ${ }^{5}$ However, electronic thermometer data remain unconvincing. All axillary temperatures need careful interpretation. The risk of rectal perforation can be lowered by more careful temperature taking and by less frequent routine determinations.

Section of Pediatric Surgery,

Department of Surgery,

University of Michigan Medical School

and C.S. Mott Children's Hospital

Ann Arbor, Michigan 48109, U.S.A.

KenNeTh PITUCh

MichaEl D. KLEIN

\section{IS HISTIOCYTIC MEDULLARY RETICULOSIS A FATAL} FORM OF INFECTIOUS MONONUCLEOSIS?

SIR,-Purtilo ${ }^{6}$ has suggested that fatal cases of infectious mononucleosis (IM) may have been misdiagnosed as leukaemia, lymphoma, or histiocytic medullary reticulosis (HMR). As an example, he cited a case of HMR in which the monospot test was positive during the patient's terminal illness, reported by Merrill and Barrett. ${ }^{7}$ In this case, the diagnosis of HMR was based on the necropsy histology and cannot readily be disregarded. There are three other reported cases of necropsy-confirmed HMR in which a positive Paul-Bunnell test had been recorded. ${ }^{8} \cdot 10$ We have reported ${ }^{11}$ a necropsy-confirmed case of HMR in which, like that of Merrill and Barrett, the monospot test was positive. Should all the abovementioned cases of HMR be re-interpreted as examples of fatal IM? To do this would be equivalent to proposing that the unique histopathology of HMR be included within the spectrum of host responses to Epstein-Barr virus (EBV) infection in man. The cause of HMR is unknown ${ }^{12}$ so that this view may be justified, and would be in accordance with suggestions of a role for EBV in the causes of lymphoma, ${ }^{13.15}$ monocytic leukaemia, ${ }^{16}$ and angioimmunoblastic lymphadenopathy. ${ }^{17}$ We have advocated wide use of the monospot test, ${ }^{11}$ because of its ready availability, in patients with malaise, pyrexia, lymphadenopathy, hepatosplenomegaly, and progressive pancytopenia; these could be cases of HMR. A positive monospot test would provide an obvious indication for EBV-specific antibody studies to be done.

Eventually, a sufficient number of HMR cases will have been investigated serologically to enable an estimate to be made of how often, if ever, a fatal EBV infection provides the necropsy histology of HMR.

Department of Renal Medicine,

Manchester Royal Infirmary,

Manchester M13 9WL, University of Manchester.

5. Buntain WL, Pregler $M$, O'Brien PC, et al. Axillary versus rectal temperature: a comparative study $\mathcal{F}$ La State Med Soc 1977; 129: 5-8.

6. Purtilo DT. Immunopathology of infectious mononucleosis. In: Sommers SC, Rosen PP, eds. Pathology annual (Parr I). New York: Appleton Century Crofts, 1980:271

7. Merrill RH, Barrett O'N. Positive mono-spot test in histrocytıc medullary reticulosis Am 7 Cln Path 1976; 65: 407-11.

8. Fowler M. Histiocytic medullary reticulosis in a child Arch Dts Child 1960; 35: $591-94$.

9. Rosenstock HA, Sandor IM, Hoenecke H. Acute histiocytic medullary retuculosis in a pubescent girl. Tex Med 1969; 65: 56-59.

10. Sehgman BR, Rosner F, Lee SL, Kagan MD. Histrocytic medullary retıculosis. Fatal haemorrhage due to massive platelet phagocytosis. Arch Intern Med 1972; 129: 109-13.

11. Davson J, Mallick NP, Lyon RLl, Geary CG. Heterophile antbody and histıcytic medullary reticulosis. Clin Lab Haemat 1981; 3: 77-84

12. Lampert IA, Catovsky D, Bergier N. Malıgnant histıcytosis: a clinico-pathological study of 12 cases. $\mathrm{Br}$ f Haemat $1978 ; 40: 65-77$.

13. Purtilo DT. Epstein-Barr virus induced oncogenesis in immune deficient individuals. Lancet 1980; i: 300-03.

14. Andersen E, Videbaek A. Infectious mononucleosis and reticulum cell sarcoma. Scand I Haemat 1972; 9: 400-02.

15. Robınson JE, Brown N, Andiman W, Hallıday K, Francke U, Robert MF, AnderssonAnvret $M$, Horstmann D, Miller G. Diffuse polyclonal B-cell lymphoma during primary infection with Epstern-Barr virus. N Engl 7 Med 1980; 302: 1293 97.

16. Hehlmann R, Walther B, Zöllner N, Wolf H, Deinhardt F. Infectıous mononucleosis and acute monocytic leukaemia. Lancet 1980; 11: 652-53.

17 Seigneurin JM, Mingar J, Lenoir GM, Couderc $P$, Micoud M. Angioimmunoblastic lymphadenopathy after infectious mononucleosis. Br Med $\mathcal{f}$ 1981; 282: 1574-75. 